\title{
ОРГАНІЗАЦЙНО-ПРАВОВІ ЗАСАДИ КОНТРОЛЮ В СИСТЕМІ СОЦІАЛЬНОГО ЗАБЕЗПЕЧЕННЯ В УКРАЇНІ НА СУЧАСНОМУ ЕТАПІ
}

\author{
Луиький начіональний технічний університет
}

\begin{abstract}
Важливим аспектом функціонування системи соціального захисту і соціального забезпечення в Україні на сучасному етапі є організація державного нагляду і контролю. Стаття присвячена аналізу організаційно-правового регулювання контролю в системі соціального захисту в Україні на сучасному етапі, в умовах реалізації Міністерством соціальної політики з 2017 року проєкту «Модернізація системи соціальної підтримки населення України» за сприяння Міжнародного банку реконструкції та розвитку. Здійснення державного контролю за дотриманням вимог законодавства у зазначеній сфері схвалено Концепцією реалізації державної політики щодо соціального захисту населення та захисту прав дітей, прийнятою Кабінетом Міністрів України у 2020 році.

У статті розкрито поняття, види та завдання державного контролю у сфері соціального захисту. Охарактеризовано суб’єкти та об'єкти контролю у сфері соціального захисту та соціального забезпечення та їх функції. Головними контролюючими органами у сфері соціального захисту $\epsilon$ Міністерство соціальної політики на Національна соціальна сервісна служба та Головні управління Національної соціальної сервісної служби у кожній області. Визначено принципи здійснення державного контролю: адресність, ефективність та законність. Встановлено, що інструментами контролю та забезпечення належного функціонування системи соціального захисту є: моніторинг, контроль (нагляд), верифікація, аудит, інспектування, оцінювання якості та ефективності надання соціальних послуг.

Охарактеризовано контролю: за дотриманням вимог законодавства під час надання соціальної підтримки (виплати, що здійснюються за рахунок коштів державного бюджету, соціальні послуги); за використанням коштів державного бюджету, виділених для надання соціальної підтримки; за дотриманням прав дітей; контроль за виплатою соціальних допомог, а також контроль за наданням соціальних послуг; за часом проведення - превентивний, поточний та ретроспективний.

Подано основні нормативні документи, які регулюють контроль за якістю надання соціальних послуг, а також за адресністю державних виплат та ефективністю використання бюджетних коштів. Встановлено, що одним із головних завдань для ефективного здійснення державного контролю у сфері соціального забезпечення стане створення Єдиної інформаційної системи соціальної сфери 3 метою забезпечення максимальної інтеграції з державними реєстрами та базами даних

Зроблено висновок, що проведення моніторингу та оцінювання якості надання соціальних послуг, здійснення державного контролю за нарахуваннями та виплатами соціальних допомог є одним 3 ключових напрямків удосконалення системи соціального захисту в Україні на сучасному етапі.

Ключові слова: сочіальний захист, сочіальне забезпечення, державний нагляд $i$ контроль, моніторинг, сочіальні виплати, сочіальні послуги, сочіальна підтримка, кошти державного бюджету.
\end{abstract}

\section{ORGANIZATIONAL AND LEGAL FRAMEWORK OF CONTROL IN THE SOCIAL WELFARE SYSTEM IN UKRAINE AT THE PRESENT STAGE}

\section{Lutsk National Tehnical University}

An important aspect of the functioning of the social protection and welfare system in Ukraine today is the organization of State supervision and control. The article is devoted to the analysis of the organizational and legal regulation of control in the system of social protection in Ukraine at the current stage, under conditions of implementation by the Ministry of Social Policy since 2017 of the project «Modernization of the system of social support of the population of Ukraine» with the assistance of the International Bank for Reconstruction and Development. The implementation of state control over compliance with the requirements of the legislation in this area is approved by the Concept of implementation of state policy on social protection and protection of children's rights, adopted by the Cabinet of Ministers of Ukraine in 2020.

The article defines the concept, types and tasks of State control in the sphere of social protection. The subjects and objects of control in the field of social protection and social security and their functions are described. The main monitoring bodies in the area of social protection are the Ministry of Social Policy, the National Social Services Center, and the National Social Services Department in each province. The basic principles of State control are defined: targeting, effectiveness and legality. It has been established that the main instruments for monitoring and ensuring the proper functioning of the social protection system are: monitoring, control (supervision), verification, auditing, monitoring, evaluation of the quality and effectiveness of the provision of social services.

The main types of control are defined: compliance with the requirements of the law in the provision of social support (payments from the State budget, social services); use of the State budget allocated for social 
support; observance of children's rights, monitoring of the payment of social benefits, as well as monitoring the delivery of social services; in terms of timing - preventive, current and retrospective.

The main normative documents regulating the control over the quality of social services, as well as the targeting of state payments and the efficiency of budget funds are presented. It is established that one of the main tasks for the effective implementation of state control in the field of social welfare will be the creation of a Unified information system of the social sphere in order to ensure maximum integration with state registers and databases.

It is concluded that monitoring and evaluating the quality of social services, state control over the accrual and payment of social benefits is one of the key areas for improving the social protection system in Ukraine at the present stage.

Key words: social protection, social welfare, state supervision and control, monitoring, social payments, social services, social support, state budget funds.

Постановка проблеми у загальному вигляді та ії зв'язок із важливими науковими чи практичними завданнями. Важливим аспектом функціонування системи соціального захисту в Україні на сучасному етапі є організація державного нагляду і контролю. Реформування системи соціального захисту в Україні має на меті забезпечення максимальної адресності надання соціальних допомог та ефективності використання бюджетних коштів. Це зумовлено зростанням категорій та кількості населення, яке потребує соціальної підтримки держави, зокрема, збільшенням кількості літніх людей, появою нових соціально вразливих категорій населення (учасники АТО/ООС, особи з інвалідністю, внутрішньо переміщені особи, сім'ї загиблих, жертви насильства тощо), що призвело до збільшення кількості соціальних виплат та звернень до соціальних служб.

Аналіз останніх досліджень і публікацій, в яких започатковано розв'язання даної проблеми. Теоретичну основу дослідження склали наукові доробки авторів щодо державного та правового регулювання соціального захисту населення українських дослідників: В.Б. Авер'янов, О.Ф. Андрійко, В.Г. Афанасьєв, О.М. Бандурка, С.Б. Кубко, Г.О. Яковлєва. Разом з тим організація моніторингу і контролю в системі соціального захисту не була предметом окремого дослідження науковців.

Цілі статті. Метою статті $\epsilon$ аналіз організаційно-правового регулювання контролю в системі соціального забезпечення в Україні на сучасному етапі.

Виклад основного матеріалу дослідження 3 повним обгрунтуванням отриманих наукових результатів. Державна політика у сфері соціального захисту та соціального забезпечення є головним стрижнем формування соціальної держави та реалізації життєвих потреб населення, особливо в умовах складних життєвих обставин.

26 серпня 2020 р. Розпорядженням Кабінетом Міністрів України було схвалено Концепцію реалізації державної політики щодо соціального захисту населення та захисту прав дітей, яка і закріплювала завдання, цілі та основні етапи у здійсненні реформи системи соціального захисту. Метою Концепції $\epsilon$ «визначення та впровадження ефективної моделі взаємодії між органами виконавчої влади та органами місцевого самоврядування для реалізації державної політики соціального захисту населення та захисту прав дітей із забезпеченням сервісного підходу до надання соціальних послуг та дотриманням принципу їх максимальної доступності для споживачів, а також здійснення державного контролю за дотриманням вимог законодавства у зазначеній сфері» [1].

Концепцією також передбачено забезпечення безперервності та послідовності реалізації державної політики у сфері соціального захисту населення, захисту прав дітей, уникнення дублювання функцій 3 питань соціального захисту населення між місцевими органами виконавчої влади та органами місцевого самоврядування тощо.

Головною метою державного нагляду й контролю у сфері соціального забезпечення є сприяння ефективній реалізації конституційного права людини на соціальне забезпечення та соціальний захист. За визначенням дослідниці Г. Яковлєвої, державний нагляд і контроль у сфері соціального забезпечення населення України - це управлінська діяльність держави (в особі державних органів та посадових осіб), що 
спрямована на забезпечення дотримання законодавства у сфері соціальнозабезпечувальних відносин [2, с. 91]. На нашу думку, ще одним важливим напрямком контролю державних органів у соціальному забезпеченні є ефективне використання бюджетних коштів та адресність соціальних допомог.

Виходячи 3 вищесказаного, головними принципами державного контролю у сфері соціального забезпечення $€$ :

1) адресність - здійснення заходів, щоб соціальна підтримка потрапляла лише до тих, хто ії дійсно потребує;

2) ефективність використання бюджетних коштів - забезпечення державного контролю при призначенні соціальних допомог;

3) законність - попередження і недопущення корупції та шахрайства як з боку державних посадовців, працівників органів соціального захисту, так і самих громадян.

На сучасному етапі головними організаційними інструментами контролю та забезпечення належного функціонування системи соціального захисту є: моніторинг, контроль (нагляд), верифікація, аудит, інспектування, оцінювання якості та ефективності надання соціальних послуг. Вони забезпечують безболісний перехід від традиційного соціального обслуговування до сучасної системи надання послуг, спрямованої на соціалізацію та підтримку особи під час свідомого, мотивованого подолання складних життєвих обставин.

Головним контролюючим органом виконавчої влади у сфері соціального захисту, діяльність якого спрямовується і координується Кабінетом Міністрів України, $\epsilon$ Міністерство соціальної політики (далі - Мінсоцполітики), яке 3-поміж інших функцій забезпечує «здійснення державного контролю за дотриманням вимог законодавства під час надання соціальної підтримки (державна допомога, пільги, житлові субсидії та інші виплати, що проводяться за рахунок державного бюджету, соціальні послуги) та за дотриманням прав дітей, а також забезпечує формування та реалізує державну політику щодо здійснення державного нагляду у сфері загальнообов'язкового державного соціального страхування від нещасного випадку на виробництві та професійного захворювання, які спричинили втрату працездатності, у зв'язку з тимчасовою втратою працездатності в частині забезпечення відповідності законодавству рішень правління Фонду соціального страхування» [3].

30 грудня 2020 року розпочала роботу Національна соціальна сервісна служба України (далі - Нацсоцслужба) - центральний орган виконавчої влади, діяльність якого «спрямовується і координується Кабінетом Міністрів України через Міністра соціальної політики і який реалізує державну політику у сфері соціального захисту населення, захисту прав дітей, а також здійснення контролю за дотриманням вимог законодавства під час надання соціальної підтримки та за дотриманням прав дітей» [4]. 31 січня 2021 року передбачено утворення територіальних органів (Головних управлінь у кожній області) Нацсоцслужби як юридичних осіб публічного права.

Початок функціонування Нацсоцслужби дасть змогу в масштабах держави сприяти розвитку якісних соціальних послуг - передусім, на рівні місцевих громад, де у них відчувається найгостріша потреба. А також дозволить за допомогою сучасних механізмів ефективно контролювати, щоб люди, які потребують соціальної підтримки, одержували іiі у повному обсязі, належної якості, відповідно до затверджених стандартів і вимог.

Відповідно до Положення «Про Національну соціальну сервісну службу», затвердженого Постановою Кабінету Міністрів України від 26 серпня 2020 р., реалізація державної політики у сфері здійснення державного контролю в системі соціального захисту включає такі «види контролю:

- за дотриманням вимог законодавства під час надання соціальної підтримки (державна допомога, пільги, житлові субсидії та інші виплати, що здійснюються за рахунок коштів державного бюджету, соціальні послуги);

- за використанням коштів державного бюджету, виділених для надання 
соціальної підтримки, зокрема під час проведення перерахунку іiі розмірів у разі встановлення фактів надмірної виплати коштів або надання іiі 3 порушенням законодавства;

- за дотриманням прав дітей» [4].

Варто виокремлювати також контроль за виплатою соціальних допомог, а також контроль за наданням соціальних послуг. За часом проведення слід виділити превентивний, поточний та ретроспективний контроль.

Держава забезпечує систему заходів, спрямованих на здійснення нагляду, аналізу, експертизи, контролю за реалізацією соціальних програм, проєктів, умовами життєдіяльності, моральним, психічним та фізичним станом дітей та молоді, забезпечення захисту їхніх прав, свобод та законних інтересів. Соціальне інспектування у сфері соціальної роботи з дітьми та молоддю здійснюється з метою контролю за додержанням вимог законодавства щодо захисту прав і свобод дітей та молоді у сфері соціальної роботи з ними.

Міністерство соціальної політики з 2017 року реалізує проєкт «Модернізація системи соціальної підтримки населення України» за сприяння Міжнародного банку реконструкції та розвитку (МБРР). Метою проекту є покращення результатів діяльності системи соціальної допомоги та соціальних послуг в Україні для малозабезпечених сімей. Одним із завдань проєкту визначено вдосконалення запровадження державного контролю за дотриманням законодавства при наданні соціальної підтримки; та інтеграції даних про виплати і послуги в єдиній інформаційній системі управління, яка охоплюватиме усі місцеві органи та установи соціальної сфери. Проект сприятиме успішному проведенню соціальних реформ, які спрямовані на зменшення рівня бідності та підвищення соціальної захищеності найбільш уразливих верств населення [5].

У рамках проєкту розроблено механізм державного контролю за адресністю та якістю надання соціальних послуг Пропонований комплексний підхід базується на успішному європейському досвіді і покликаний мотивувати надавачів соціальних послуг забезпечувати більш якісну підтримку тим, хто іiї передусім потребує .

Особлива увага у ході державного контролю надання соціальних послуг приділятиметься забезпеченню дотримання прав людини і прав дитини - особливо, у закладах стаціонарного проживання та цілодобового соціального обслуговування. Також перевірятиметься використання ресурсів під час надання соціальних послуг, наявність у надавача фахівців необхідного рівня кваліфікації, відповідних приміщень, обладнання тощо.

В ході реалізації проєкту розроблені методичні рекомендації, що визначають відповідність організації надання тієї чи іншої соціальної послуги, а також порядок та спосіб здійснення контролю. Процес здійснення перевірки повинен бути неупередженим, прозорим i зрозумілим усім його учасникам. Адже важливим завданням державного контролю $є$ співпраця з надавачами соціальних послуг з метою вдосконалення їх роботи та розвитку якісних соціальних сервісів, доступних для людей. Пілотні перевірки відбудуться у шести установах, що надають соціальні послуги догляду вдома, стаціонарного догляду та соціального супроводу. Це територіальні центри соціального обслуговування (надання соціальних послуг), будинки-інтернати для громадян похилого віку та осіб 3 інвалідністю, центри соціальних служб для сім “ї, дітей та молоді. Отриманий досвід дозволить вдосконалити механізми контролю для їх подальшого поширення в масштабах держави [6].

Суб'єктами моніторингу і контролю процесу планування та надання соціальних послуг можуть виступати як державні/муніципальні установи, так і громадські організації, які працюють у сфері забезпечення соціального захисту в країні.

Дослідниця Г. Яковлєва, систематизувала «функції суб'єктів державного нагляду і контролю у сфері соціального забезпечення населення України:

- регулююча (корегуюча) функція, яка спрямована на виявлення розходжень між 
заданими й фактичними діями, шляхами, обраними для досягнення мети, та прийняти рішення і спрямування рішень на виправлення ситуації;

- профілактична - спрямована на попередження порушення законодавства, яке спрямоване на регулювання сфери соціального забезпечення;

- правоохоронна функція державного нагляду й контролю у сфері соціального забезпечення населення України полягає в тому, щоб припинити неправомірні дії відповідних органів та їхніх посадових осіб, а також щоб забезпечити реалізацію й захист конституційного права людини на соціальне забезпечення. Ця функція тісно пов'язана з притягненням до юридичної відповідальності та із застосуванням заходів державного примусу;

- інформаційна функція, що забезпечить суб'єктові управління можливість отримати інформацію про стан справ у сфері його інтересів, про результати управлінського впливу, відповідність діяльності об'єкта чи об'єктів управління визначеним завданням» [2, с. 92].

Об’єктами державного контролю у сфері соціального забезпечення є:

- органи, установи та організації, що призначають, нараховують та/або здійснюють державні виплати;

- надавачі соціальних послуг - юридичні особи та фізичні особи - підприємці;

- надавачі соціальних послуг - фізичні особи;

- громадяни України, які користуються правом отримання соціальних допомог;

- отримувачі соціальних послуг.

Протягом 2019-2020 років було розроблено цілу низку нормативних документів, які дадуть змогу створити алгоритм прозорості ринку надавачів послуг та реєстрації відповідних суб'єктів, забезпечити контроль за якістю надання соціальних послуг [7], а також за адресністю державних виплат та ефективністю використання бюджетних коштів [8; 9].

У Законі України «Про верифікацію та моніторинг державних виплат» встановлено, що «контроль (верифікацію та моніторинг) за державними виплатами, зокрема, пенсіями, допомогами, субсидіями, соціальними стипендіями та іншими виплатами, що здійснюються за рахунок коштів державного, місцевих бюджетів, фондів загальнообов'язкового державного соціального і пенсійного страхування, здійснюватиметься центральним органом виконавчої влади, що забезпечує формування та реалізує державну фінансову та бюджетну політику» [8]. «Відповідно до Статті 1 Закону «верифікація - це комплекс заходів щодо збору та перевірки достовірності інформації, що визначена законодавством для призначення, нарахування та/або здійснення державних виплат і впливає на визначення права на отримання та розмір таких виплат, а також на виявлення невідповідності даних у автоматизованих інформаційних системах, реєстрах, базах даних. Законом визначено превентивну (під час звернення громадянина), поточну (під час нарахування та або здійснення державних виплат реципієнту), а також ретроспективну верифікацію (після завершення державних виплат) верифікацію» [8].

У січні 2021 року Кабінетом Міністрів затверджено Порядок формування, ведення та доступу до Реєстру надавачів та отримувачів соціальних послуг (до 1 червня 2022 р. повинно бути забезпечено наповнення Реєстру надавачів та отримувачів соціальних послуг інформацією 3 використанням даних, наявних в інших інформаційних системах, що використовуються обласними, Київською міською, районними, районними у м. Києві державними адміністраціями, виконавчими органами сільських, селищних, міських рад під час надання соціальних послуг) [10].

На підставі затвердженої 27 січня 2021 року Урядом Постанови "Про Реєстр надавачів та отримувачів соціальних послуг» Міністерство соціальної політики повинно забезпечити до 1 червня 2022 року наповнення Реєстру надавачів та отримувачів соціальних послуг інформацією з використанням даних, наявних в інших інформаційних системах. Органам місцевого самоврядування, а отже й центрам соціальних служб та територіальним центрам соціального обслуговування (надання 
соціальних послуг), або створеним на їх основі центрам надання соціальних послуг рекомендовано до 30 червня 2022 р. використовувати зведену інформацію про надавачів та отримувачів соціальних послуг, опубліковану на офіційному веб-сайті Міністерства соціальної політики, а після 30 червня 2022 р. - Реєстр надавачів та отримувачів соціальних послуг [10].

Інформація 3 Реєстру буде використовуватися для здійснення відповідних контрольних заходів. Це сприятиме систематичному контролю за надавачами послуг, особливо в частині зловживань, порушення законності, захисту прав людини та недопущення трагічних випадків. Шкода, що посилення уваги державних органів до контролю відбувається після трагічних випадків, як наприклад, у Харківському приватному пансіонаті, який здійснював догляд за громадянами похилого віку (21 січня 2021 року там сталась пожежа і загинули люди). Інформацію про зазначений суб'єкт господарювання не було занесено до жодного реєстру, органи соціального захисту населення також не знали про діяльність цього суб'єкта.

Організація контролю у сфері соціального захисту до реформи соціальної сфери була покладена на департаменти соціальної політики або департаменти (управління) соціального захисту населення міських (у великих містах), районних та обласних адміністрацій, а також на відповідні відділи або центри соціальних служб у територіальних громадах, територіальні відділення Фонду соціального страхування.

Державний нагляд (контролю) за дотриманням роботодавцями законодавства про зайнятість та працевлаштування осіб з інвалідністю у частині реєстрації у Фонді соціального захисту інвалідів, подання звітів про зайнятість та працевлаштування осіб з інвалідністю, виконання нормативу робочих місць, призначених для їх працевлаштування, здійснює Державна служба України з питань праці.

Важливим завданням для ефективного здійснення державного контролю у сфері соціального забезпечення є створення Сдиної інформаційної системи соціальної сфери, що дасть змогу максимально інтегрувати державні реєстри та бази даних. В листопаді 2020 року Кабінет Міністрів України затвердив Постанову «Про запровадження експериментального проекту 3 реалізації функціоналів першої черги Єдиної інформаційної системи соціальної сфери». Завданнями експериментального проекту (впродовж листопада 2020 року - березня 2021 року) було відпрацювання технології формування Єдиного соціального реєстру на базі реєстру застрахованих осіб Державного реєстру загальнообов'язкового державного соціального страхування та на базі Пенсійного фонду України, а також технології централізованої обробки даних для надання електронних послуг та забезпечення електронної інформаційної взаємодії Єдиної інформаційної системи соціальної сфери із централізованим банком даних 3 проблем інвалідності, а також з Сдиним державним веб-порталом електронних послуг “Портал Дія" для забезпечення дистанційного доступу громадян до всіх послуг, що надаються інституціями соціальної сфери [11].

Завдяки цьому можна буде перевірити та отримати інформацію в електронному вигляді про соціальний статус громадянина; загальнообов'язкове державне соціальне страхування; пенсійне посвідчення та пенсійну справу; інформацію інвалідність особи (групу, підгрупу, причину інвалідності та строк, на який ії призначено).

В грудні 2020 року Мінсоцполітики разом 3 Міністерством цифрової трансформації подало на розгляд Кабінету Міністрів України проєкт Положення про Єдину інформаційну систему соціальної сфери, який з лютого по березень 2021 року був винесений на громадське обговорення [12].

Формування Єдиної інформаційної системи соціальної сфери сприятиме поступовій відмові від паперових довідок та документів, які необхідні для визначення права особи на державні допомоги та пільги; забезпечить організацію верифікації та моніторингу державних виплат, а також контролю за якістю надання соціальних послуг.

3 метою реалізації указу Президента України від 29 січня 2021 року № 30 „Про 
деякі заходи щодо забезпечення права громадян на якісні та безпечні соціальні послуги” Урядом прийнято постанову „Про утворення робочої групи 3 питань удосконалення законодавства щодо розвитку і регулювання ринку соціальних послуг” [13]. Постановою передбачено «створення робочої групи для напрацювання пропозицій 3 удосконалення законодавства щодо посилення державного нагляду (контролю) у сфері надання соціальних послуг та затвердження дозвільних (погоджувальних) процедур, надання дозвільних документів для провадження діяльності у сфері надання соціальних послуг» [13]. Створення робочої групи допоможе напрацювати механізми стимуляції і розвитку ринку соціальних послуг, контролю і відповідальності у сфері їх надання.

Висновки. Отже, державний нагляд і контроль у сфері соціального забезпечення населення України має дуже важливе значення. По-перше, для людини, оскільки він дозволяє попередити порушення іiі конституційного права на соціальне забезпечення, а також дозволяє повною мірою скористатися цим правом; по-друге, для держави, оскільки ефективне здійснення нагляду й контролю за цією сферою дозволить збільшити рівень довіри населення до держави та іiї органів. Щоб нагляд і контроль за зазначеною сферою був ефективним, він повинен здійснюватися в рамках чинного законодавства України, мати систематичний характер, проводитися своєчасно, і бути результативним.

На сучасному етапі реформування соціальної сфери та в процесі реалізації Міністерством соціальної політики проєкту «Модернізація системи соціальної підтримки населення України» розроблено та прийнято значну кількість нормативних документів для забезпечення державного контролю при призначенні різних видів соціальних допомог, субсидій і пільг на житлово-комунальні послуги та при наданні соціальних послуг. Організаційно-правове забезпечення здійснення контролю у сфері соціального захисту є вкрай важливим завданням, оскільки порушення законодавства можуть бути як з боку державних посадовців, так і з боку самих громадян.

Проведення моніторингу та оцінювання якості надання соціальних послуг, здійснення державного контролю за нарахуваннями та виплатами соціальних допомог $\epsilon$ одним з ключових напрямків удосконалення системи соціального захисту в Україні на сучасному етапі.

\section{Список бібліографічного опису:}

1.Про схвалення Концепції реалізації державної політики щодо соціального захисту населення та захисту прав дітей. Розпорядження Кабінету Міністрів України від 26 серпня 2020 p. № 1057-p. URL: https://zakon.rada.gov.ua/laws/show/1057-2020-\%D1\%80\#Text

2.Яковлєва Г. Державний нагляд і контроль у сфері соціального забезпечення населення України. Підприємниитво, господарство і право. 2017. № 4. C.90-93. URL: http://nbuv.gov.ua/UJRN/Pgip_2017_4_20

3.Про затвердження Положення про Міністерство соціальної політики України: постанова Кабінету Міністрів України від 17.06.2015 р. № 423. URL: https://zakon.rada.gov.ua/laws/show/423-2015-\%D0\%BF\#Tехt (дата звернення 20.09.2020).

4. Деякі питання Національної соціальної сервісної служби України: постанова Каб. Міністрів України від 26.08.2020р. № 783. Урядовий кур'єр. 2020.5 верес. C. 10-11. URL: https://zakon.rada.gov.ua/laws/show/783-2020-\%D0\%BF\#n44

5.Проєкт, що підтримуються МБРР / Мінітерство соціальної політики. Вебсайт: URL: https://www.msp.gov.ua/timeline/Proekti-shcho-pidtrimuyutsya-

MBRR.html?fbclid=IwAR2RcF5EemR9T7oBRaXgYY1sQmbK-6dp-EF-ntidcRVWECnFKAmHKrAFR_A звернення 20.03.2021 p.)

6.Мінсоцполітики посилить увагу до якості соціальних послуг для найменш захищених громадян/ Мінітерство соціальної політики. Вебсайт:. URL: https://www.msp.gov.ua/news/18931.html дата звернення 12.03.2021р.)

7. Деякі питання здійснення контролю за додержанням вимог Закону України «Про соціальні послуги»: постанова Каб. Міністрів України від 01.06.2020 р. № 427. Урядовий кур'єр. 2020. 3 черв. С. 5.; Про затвердження Порядку проведення моніторингу надання та оцінки якості соціальних послуг: постанова Каб. Міністрів України від 01.06.2020 р. № 448 . Урядовий кур'єр. 2020. 6 черв. С. 5-6.

8.Про верифікацію та моніторинг державних виплат. Закон України від 3 грудня 2019 року № 324-IX. Відомості Верховної Ради України, 2020, № 11, ст.63. URL: https://zakon.rada.gov.ua/laws/show/324-20\#Text;;

9.Про затвердження Порядку здійснення верифікації та моніторингу державних виплат. Постанова Кабінету міністрів від 18 лютого 2016 р. № 13. Із змінами, внесеними згідно з Постановами КМ № 443 від 22.05.2019 № 205 від 03.03.2020. URL: https://zakon.rada.gov.ua/laws/show/136-2016-\%D0\%BF\#n10

10. Про Реєстр надавачів та отримувачів соціальних послуг: постанова Кабінету Міністрів України від 27 січня 2021 p. № 99. URL: https://zakon.rada.gov.ua/laws/show/99-2021-\%D0\%BF\#Text

11. Про запровадження експериментального проекту з реалізації функціоналів першої черги Єдиної інформаційної системи соціальної сфери: постанова Кабінету Міністрів України від 11.11.2020 р. № 1278 URL: https://zakon.rada.gov.ua/laws/show/1278-2020-\%D0\%BF\#n30 
12. Проєкт Про затвердження Положення про Єдину інформаційну систему соціальної сфери URL: https://www.msp.gov.ua/projects/653/

13. Про утворення робочої групи з питань удосконалення законодавства щодо розвитку і регулювання ринку соціальних послуг. Постанова Кабінету міністрів від 17 лютого 2021 р. № $125 . \quad$ URL: https://zakon.rada.gov.ua/laws/show/125-2021-\%D0\%BF\#Text

\section{References:}

1.Pro skhvalennya Kontseptsiyi realizatsiyi derzhavnoyi polityky shchodo sotsial'noho zakhystu naselennya ta zakhystu prav ditey. Rozporyadzhennya Kabinetu Ministriv Ukrayiny vid 26 serpnya 2020 r. № 1057-p. URL: https://zakon.rada.gov.ua/laws/show/1057-2020-\%D1\%80\#Text

2.Yakovlyeva H. Derzhavnyy nahlyad i kontrol' u sferi sotsial'noho zabezpechennya naselennya Ukrayiny. Pidpryyemnytstvo, hospodarstvo i pravo. 2017. № 4. S.90-93. URL: http://nbuv.gov.ua/UJRN/Pgip_2017_4_20

3.Pro zatverdzhennya Polozhennya pro Ministerstvo sotsial'noyi polityky Ukrayiny: postanova Kabinetu Ministriv Ukrayiny vid 17.06.2015 r. \# 423. URL: https://zakon.rada.gov.ua/laws/show/423-2015-\%D0\%BF\#Text (data zvernennya 20.09.2020). 4.Deyaki pytannya Natsional'noyi sotsial'noyi servisnoyi sluzhby Ukrayiny: postanova Kab. Ministriv Ukrayiny vid 26.08.2020 r. № 783. Uryadovyy kur"yer. 2020. 5 veres. S. 10-11. URL: https://zakon.rada.gov.ua/laws/show/783-2020$\% \mathrm{D} 0 \% \mathrm{BF} \# \mathrm{n} 44$

5.Proyekty, shcho pidtrymuyut'sya MBRR / Miniterstvo sotsial'noyi polityky. Vebsayt: URL: https://www.msp.gov.ua/timeline/Proekti-shcho-pidtrimuyutsya-

MBRR.html?fbclid=IwAR2RcF5EemR9T7oBRaXgYY1sQmbK-6dp-EF-ntidcRVWECnFKAmHKrAFR_A zvernennya 20.03.2021 r.)

6.Minsotspolityky posylyt' uvahu do yakosti sotsial'nykh posluh dlya naymensh zakhyshchenykh hromadyan/ Miniterstvo sotsial'noyi polityky. Vebsayt:. URL: https://www.msp.gov.ua/news/18931.html data zvernennya 12.03.2021 r.)

7.Deyaki pytannya zdiysnennya kontrolyu za doderzhannyam vymoh Zakonu Ukrayiny «Pro sotsial'ni posluhy»: postanova Kab. Ministriv Ukrayiny vid 01.06.2020 r. \# 427. Uryadovyy kur"yer. 2020. 3 cherv. S. 5.; Pro zatverdzhennya Poryadku provedennya monitorynhu nadannya ta otsinky yakosti sotsial'nykh posluh: postanova Kab. Ministriv Ukrayiny vid 01.06.2020 r. \# 448. Uryadovyy kur"yer. 2020. 6 cherv. S. 5-6.

8.Pro veryfikatsiyu ta monitorynh derzhavnykh vyplat. Zakon Ukrayiny vid 3 hrudnya 2019 roku \# 324-IX. Vidomosti Verkhovnoyi Rady Ukrayiny, 2020, \# 11, st.63. URL: https://zakon.rada.gov.ua/laws/show/324-20\#Text;;

9.Pro zatverdzhennya Poryadku zdiysnennya veryfikatsiyi ta monitorynhu derzhavnykh vyplat. Postanova Kabinetu ministriv vid 18 lyutoho 2016 r. \# 13. Iz zminamy, vnesenymy z·hidno z Postanovamy KM \# 443 vid 22.05.2019 \# 205 vid 03.03.2020. URL: https://zakon.rada.gov.ua/laws/show/136-2016-\%D0\%BF\#n10

10. Pro Reyestr nadavachiv ta otrymuvachiv sotsial'nykh posluh: postanova Kabinetu Ministriv Ukrayiny vid 27 sichnya 2021 r. \# 99. URL: https://zakon.rada.gov.ua/laws/show/99-2021-\%D0\%BF\#Text

11. Pro zaprovadzhennya eksperymental'noho proektu z realizatsiyi funktsionaliv pershoyi cherhy Yedynoyi informatsiynoyi systemy sotsial'noyi sfery: postanova Kabinetu Ministriv Ukrayiny vid 11.11.2020 r. \# 1278 URL: https://zakon.rada.gov.ua/laws/show/1278-2020-\%D0\%BF\#n30

12. Proyekt Pro zatverdzhennya Polozhennya pro Yedynu informatsiynu systemu sotsial'noyi sfery URL: https://www.msp.gov.ua/projects/653/

13. Pro utvorennya robochoyi hrupy z pytan' udoskonalennya zakonodavstva shchodo rozvytku i rehulyuvannya rynku sotsial'nykh posluh. Postanova Kabinetu ministriv vid 17 lyutoho 2021 r. № 125. URL: https://zakon.rada.gov.ua/laws/show/125-2021-\%D0\%BF\#Text

Дата подання публікації 01.04.2021 p.

УДК 364:005.591.6(477)

Савченко В.Ф., д.е.н., професор

Уманський державний педагогічний університет імені Павла Тичини V.F. Savchenko, Doctor of Economic Sciences,Professor PavloTychynaUman State Pedagogical University https://orcid.org/0000-0001-7637-2124 Маклюк О.В., викладач

Чернігівський інститут імені Героїв Крут Приватного акціонерного товариства «Вищий навчальний заклад «Міжрегіональна Академія управління персоналом»

Oleh Makliuk, Lecturer

Chernihiv Institute named after Heroes of Kruty PJSC Private Joint-Stock Company «Higher education institution «Interregional Academy of Personnel Management» https://orcid.org/0000-0002-7429-692X

\section{ІННОВАЦЙНІ ПІДХОДИ ДО РОЗВИТКУ СОЦАЛЬНОЇ СФЕРИ УКРАЇНИ}

Уманський державний педагогічний університет імені Павла Тичини,

Чернігівський інститут імені Героїв Крут Приватного акціонерного товариства «Вищий навчальний заклад «Міжрегіональна Академія управління персоналом» 
Метою статті є аналіз теоретичних положень, світового досвіду та ситуації в Україні щодо соціальної сфери, іiї показників, досягнень та недоліків, надання і обгрунтування пропозицій відносно шляхів розвитку, окреслення питань подальших наукових досліджень у даному спрямуванні. Методологічною основою дослідження є використання методів теоретичного узагальнення, 